DOI: https://doi.org/10.24297/jssr.v15i.8643

\title{
Insignificant Relationship Between Speaking Self-Efficacy and Language Learning Anxiety of English Department Students at The University of Riau, Indonesia
}

\author{
Hadriana \\ Faculty of Teacher Training and Education (University of Riau, Indonesia) \\ hadriana@lecturer.unri.ac.id
}

\begin{abstract}
Many studies have delved into the connection between self-efficacy and language anxiety. However, the findings are somewhat inconsistent: self-efficacy has either positive, negative, or no relationship at all with language anxiety. Therefore, this research aims to examine the relationship between students' self-efficacy and language anxiety in learning speaking in EFL classroom. The subjects of this study were second-year English Department students at the University of Riau, Indonesia, taking Speaking subject $(N=40)$. Data on their self-efficacy and language anxiety were collected through questionnaire. The data analysis results reveal that the students have very good self-efficacy in speaking. They also show a moderate level of anxiety. However, statistical analysis reveals that there is no relationship between the two variables. Despite the limited number of participant, this finding is expected to shed a light on the contribution of self-efficacy and anxiety on learning speaking in EFL context. This finding suggests that although the self-efficacy and anxiety levels were similar with previous studies, there might be different patterns of relationship between these variables depending on the context. This implies that teachers should be aware of this before taking any measure to improve students speaking skill.
\end{abstract}

Keywords: Self-Efficacy, Language Anxiety, Speaking, Efl Classroom

\section{Introduction}

In Indonesia, English is considered as a foreign language. Its usage is vital in many sectors, such as education, technology, business, tourism, banking, and many others. Realizing the importance of English, the government has classified English subject as a compulsory subject to be taught from junior high schools up to university levels. Although the learning objectives of each level are different, they basically consist of two aspects: the ability to comprehend a text and the ability to communicate. Thus, when studying English, the students are trained to master the four language skills, namely reading, listening, writing, and speaking skills, so that they can communicate and discourse in English at certain literacy level.

However, many studies investigating speaking skill in EFL classroom, one of which is conducted by Hamouda (2012), show that in non-English speaking schools, many students tend to show hesitation in speaking English in the classroom. He highlights some factors which cause this unwillingness, such as anxiety, lack of interest, lack of confidence, and low self-belief. It is also found out that they have a relatively average or even good level of speaking skills, but they felt afraid to use English. They often prefer to communicate with friends and lecturers using their mother tongue when they are not in the classroom. It might be influenced by several reasons, such as self-esteem, personality, anxiety, and efficacy issues. Individual differences, such as gender and age, may also contribute to their language learning process. In another case, the students are eager to speak English but losing for words during delivering the speech. As a result, their speaking performances end up poorly.

The issue of language learners' performance in English has withdrawn much attention in educational research. Many researchers seek a correlation of this issue with a various degree of motivation (Bandura, 2006; Cook, 2000; Thayne, 2013), self-efficacy (Gardner, 1985; Schunk, 1991), and anxiety (Horwitz \& Young, 1991). It is often found that these three factors are interrelated to each other (Piniel \& Csizer, 2013). Even though many studies looking at these factors and their influence on language learners' performance, the relationship between self- 
efficacy and language learning anxiety seems underexplored, especially in Indonesian EFL context. Recently, studies on motivation and self-efficacy have gained much attention in Indonesia. However, there is still a gap in the literature which looks at how students' belief and their anxiety level influence their speaking performance. Therefore, this study aims to explore the linkage between students' speaking self-efficacy and their level of language learning anxiety by answering the following questions: (1) To what extent is Language learning anxiety manifested in Indonesian EFL learners? And (2) Is there any relationship between language learning anxiety and students' speaking self-efficacy?

\section{Literature Review}

\section{Self-Efficacy}

Bandura (1997) says that self-efficacy is someone's belief on capabilities to do an assignment to achieve specified goals. It concerns more with what he can do rather than what skills he has. In a classroom context, a student who believes that his performance is good will be motivated to work hard to get good results. On the contrary, a student who has a low self-efficacy level thinks that the task given is very hard, difficult, or boring. Consequently, he does not enjoy doing the task.

Tilfarlioglu and Cinkara (2009) describe that in cognitive system, self-efficacy acts as a central element of motivation and effort. This idea is in line with Schunk (1991), who says that self-efficacy generates, enhances, and sustains motivation. When students know that they are getting better at certain second language skills, they will start developing higher levels of self-efficacy which can enhance their learning motivation. According to Bandura (1995), learner's efficacy can be developed through these four sources:

1. Mastery experiences. Mastery experiences are a person's experiences of success. This is a very powerful source of self-efficacy and will enhance the positive perception of ability and believes in own competence.

2. Vicarious experiences. Vicarious experiences are obtained by observing others. It involves self-evaluation that is obtained through observation and comparison of himself with 'a model' (classmate, a friend, etc whose traits and skills are comparable to his). When the student sees that this 'model' manages to accomplish a given task, he is likely to feel able to face a similar challenge.

3. Social persuasion. The impact of social persuasion to self-efficacy depends on the credibility of the person giving the message in the eyes of the person receiving it. Positive persuasion may improve self-efficacy, and negative persuasion seems lowering self-efficacy.

4. Physiological and emotional state. This aspect is related to someone's emotional state, such as fatigue, illness, aches, mood, anxiety, stress, etc. All of these situations may affect how someone judges their efficacy.

According to Bandura (1986), improving self-efficacy could be done by providing students with motivational support and guidance. This implies teacher's pivotal role in inculcating positive self-perceptions of efficacy. Another opinion about self-efficacy is given by Cubukcu (2008). He says that self-efficacy is related to students' learning engagement which comprises of their behaviour, cognitive ability, and learning motivation. On behavioral engagement, teachers are able to see clearly if the students engage with the activity through their effort, perseverance, and help-seeking behaviour. If they do not believe in themselves, they tend to drop a task easily. In contrast, teacher cannot observe cognitive engagement as it lies in students' minds. Students who have high efficacy level tend to utilize cognitive strategies more than their peers when immersing themselves in learning. Motivational engagement includes preferences, priority scale and effect. In short, self-efficacy can positively influence the students to engage with academic circumstances which lead to better learning achievement. 
To conclude, the meaning of self-efficacy in this research is a student's awareness and belief that may influence how he feels, thinks, motivates himself, and behave to be successful in speaking class. The components of selfefficacy used are students' awareness of speaking, students' beliefs about their capacity, and factors that influence self-efficacy.

\section{Language Learning Anxiety in EFL Classroom}

Language Learning Anxiety has gained popularity in EFL research in the last decade. Many studies suggest that anxiety is one of the key factors hampering students' attainment in learning a foreign language. However, such anxiety is different from common anxiety, which people generally experience in certain circumstances (Horwitz, Horwitz, \& Cope, 1986). As language anxiety is believed to have a distinctive characteristic, many studies have explored the extent to which students experience it in their learning. Most, if not all, of the studies have shown relatively similar findings.

Some studies which delved into the level of students' language anxiety have shown that students have had moderate to high level of foreign language anxiety (Alrabai, 2014; Alsowat, 2016; Burden, 2004; Suleimenova, 2012; Tianjian, 2010). Within this level of anxiety, students most likely feel anxious in terms of the worry of negative feedback, making mistakes, and vocabulary limitation (Sadighi \& Dastpak, 2017). However, it is also found that the degree of language anxiety between male and female students is relatively similar (Ozuturk \& Hursen, 2013; Shabani, 2012).

\section{Language Anxiety and Self-efficacy}

As findings of previous studies have highlighted the significant level of anxiety among EFL learners, researchers start to investigate how this anxiety affects students' learning and how it correlates with other aspects, such as motivation, language proficiency, learning achievement, and self-efficacy. With many emerging studies on this topic, only a few of them focus on the connection between language anxiety and self-efficacy (Cubukcu, 2008). Even if there are some studies investigating the correlation, the findings are varied.

From some reliable studies to date, there are three different findings regarding the relation between self-efficacy and language anxiety, namely positive, negative, and no correlation. A study conducted by Tuncer \& Dogan (2016) finds language anxiety and self-efficacy correlate positively. This study suggests that higher self-efficacy will trigger higher language anxiety. However, other studies found the opposite findings, which highlight a negative correlation between these two variables (Bensalem, 2018; Mede \& Karairmak, 2017; Piniel \& Csizer, 2013; Tsai, 2013). These studies suggest that higher self- efficacy will lower language anxiety and vice versa. Different from these two findings, a study conducted by Cubukcu (2008) shows that language anxiety and selfefficacy has no correlation towards each other.

The different findings emerged from the previous studies might be due to the different methodologies employed by the researchers and the context of the place where the studies are conducted. Besides, the individual differences might also add up to the variation. Diversity of findings from limited numbers of research exploring the correlation between self-efficacy and language anxiety speak to the need for further research on the topic with different context and methodology. Therefore, this study aimed at exploring the correlation between language anxiety and self-efficacy of EFL learners in Indonesian context. This study is expected to give new insight into the understanding of students' anxiety in EFL classroom and its correlation with their selfefficacy belief.

\section{Materials and Methods}

\section{Participants}

The participants of this study are the second-year students of English Education Department - University of Riau, Indonesia academic year 2017-2018. Of 78 students, 40 students who were taking Speaking class were 
asked to be the sample of the study. They were chosen because they were currently enrolled in Speaking subject so that their response might be more relevant to this study than those who were not enrolled.

\section{Instrumentation}

Two instruments were administered to collect data for this research. The first instrument was a questionnaire on students' self-efficacy in learning speaking. This questionnaire was designed according to the framework of selfefficacy given by Bandura (1997), Cubukcu (2008), and Paradewari (2017). It consisted of 20 statements. The students were instructed to read every item and then decided if they: (1) strongly disagree, (2) disagree, (3) Neutral, (4) agree, and (5) strongly agree. The other research instrument was a questionnaire of language learning anxiety which was adapted from Horwitz, Horwitz \& Cope (1986). This questionnaire consisted of 33 items. The questionnaires were pilot tested on 20 students who were not in the actual research. The Cronbach alpha of self-efficacy was 0.79 and The Cronbach alpha of language learning anxiety was 0.86 .

\section{Data Analysis}

Some statistical analyses were done in analyzing the data of this research: (1) Descriptive analysis on self-efficacy and language learning anxiety; (2) Descriptive statistical analyses such as Cronbach alphas, means, and standard deviations were used to analyse the students' answers to the questionnaires. (3) Pearson correlation was applied to inquire into the correlation of the students' self-efficacy on their speaking skill and their language learning anxiety.

\section{Results and Discussion}

\section{Students' Self-Efficacy in Learning Speaking}

Based on questionnaire analysis, the students' self-efficacy in learning speaking can be seen in Table 1.

Table 1. Students' Self-efficacy in Learning Speaking

No Statement

$1 \quad$ I posses sufficient ability to speak English with my lecturers and classmates.

$4.55 \quad 0.60$

2 I can push myself to improve my speaking skill.

3 I can give a structured speech in my Speaking class.

$4 \quad$ I can keep up my body position when giving the speech.

I can clarify the speech material so that my lecturers and classmates can grasp what I say.

6 I regard myself as a good English speaker.

7 I am a good English speaker in my speaking class.

8 I am able to give a speech confidently.

9 I can try harder to maintain my speech during the time given.

10 When giving a speech, I am well prepared for unexpected situations. 
11 I am able to discover a way to say what I mean to say even if the speaking topic is challenging, and I don't have the pertinent vocabulary.

12 I believe I can get better score in Speaking class if I practice speaking more.

13 I am an active student in my speaking classes.

14 I am able to improve my speaking skills

15 I regard myself as a credible English speaker, as I am able to give a speech clearly.

16 I am confident about English speaking skill, whether in class or outside.

17 I have a role model for effective speech delivery.

18 I can use facial expressions and gestures when delivering my speech.

19 I am relieved when I have done giving my speech.

20 My classroom atmosphere motivates me to improve my speech delivery.

Table 1 illustrates the students' self-efficacy in learning Speaking. It can be seen that the students have very good self-efficacy. The highest score belongs to item 16, which shows that they feel confident to speak with other English speakers anywhere $(M=4.66)$. The next highest scores belong to item 1 and 7, "I posses sufficient ability to speak English with my lecturers and classmates." and "I am a good English speaker in my speaking class", with $M=4.50$ respectively. This indicates that they have a high efficacy level in terms of their English speaking ability. However, the lowest score of students self-efficacy belongs to item 19, "I feel relieved and delighted after delivering my speech", with a mean score 4.15. Even though the mean score is still high, the students seem not to feel strongly on this compared to other items. This might be related to their emotional state after delivering a speech.

\section{Students' Language Anxiety in Learning Speaking}

Based on questionnaire analysis, the students' anxiety in learning speaking can be seen in Table 2 .

Table 2. Students' Language Learning Anxiety in Learning Speaking

\begin{tabular}{llcc}
\hline No. & Statement & Mean & SD \\
\hline 1 & I doubt myself when I speak English in my Speaking class. & 2.93 & 0.83 \\
2 & I rarely concern about making any mistakes in Speaking class. & 3.00 & 1.15 \\
3 & I feel scared when I realise that my lecturer will ask me to speak in Speaking class. & 3.40 & 1.17 \\
4 & I am scared when I get confused about my lecturer's explanation. & 2.95 & 1.34 \\
5 & I am keen on joining more Speaking classes. & 3.43 & 1.17 \\
6 & My mind cannot focus on the lesson during Speaking class. & 2.68 & 0.94 \\
7 & I believe that my classmates are better at speaking English than I am. & 3.78 & 0.83
\end{tabular}


8 I normally feel comfortable when doing tests in my Speaking class.

9 I feel anxious and nervous when I am asked to give an impromptu speech in Speaking class.

10 I am afraid of being failed in my Speaking class.

11 I cannot understand why people have negative feeling toward Speaking classes.

12 In Speaking class, my mind can go blank due to nervousness.

13 I am embarrassed to answer questions given in my Speaking class.

14 I feel confident to speak English with native speakers.

15 I feel bad when I get confused about my lecturer's feedback.

16 I am still anxious about giving a speech in Speaking class even if I have prepared well for it.

17 I sometimes feel hesitated to attend my Speaking class.

18 I feel confident to speak in Speaking class.

19 I feel worried that my Speaking lecturer is attentive to my mistakes.

20 When my turn is coming in Speaking class, my heart beats faster.

21 I get more confused when I study for my speaking exam.

22 I am at ease when I have to prepare for my Speaking class.

23 I keep thinking that my classmates are better English speakers than I am.

24 I am highly aware of my speech in front of my classmates.

25 I am afraid of being left behind as I think the class' pace is so fast.

26 Compared to in other classes, I am more uneasy and nervous in my Speaking class.

27 I feel confused and nervous when speaking in my Speaking class.

28 I am relaxed when I am on my way to my Speaking class.

29 I am uneasy when I cannot follow what my Speaking lecturer says.

30 I am stressed out by many rules speaking English has.

31 I feel worried that I will be laughed at by my classmate when speaking English. 
33 I am nervous when having to answer unexpected questions from my Speaking lecturer.

Table 2 illustrates students' anxiety in learning Speaking. Overall, it can be seen that the students have a moderate anxiety level $(M=3.24)$. The highest levels of anxiety are found to be item 9,12 and 23, "I feel panic and nervous when I am asked to give an impromptu speech in Speaking class", "In Speaking class, my mind can go blank due to nervousness" and "I keep thinking that my classmates are better English speakers than I am.", with means scores 4.10, 3.93 and 3.93 respectively. This suggests that students are anxious when having to speak without preparation. They also feel that their speaking ability is not as good as their peers. The lowest score of anxiety belongs to item 21, "I get more confused when I study for my speaking exam", with mean score 2.03. This suggests that the students feel that they have a better understanding when they study for the speaking test.

\section{Relationship between Language Anxiety and Speaking Self-efficacy}

Pearson Correlation was utilized to explore the relationship between language anxiety and self-efficacy. The calculation results are in the following table.

Table 3. Pearson Correlation Analysis on Language Anxiety and Self-efficacy

\begin{tabular}{llll}
\hline & & $\begin{array}{l}\text { Language } \\
\text { Anxiety }\end{array}$ & Self-Efficacy \\
\hline Language Anxiety & Pearson Correlation & 1 & .215 \\
& Sig. (2-tailed) & & .182 \\
& N & 40 & 40 \\
Self-Efficacy & Pearson Correlation & .215 & 1 \\
& Sig. (2-tailed) & .182 & \\
& N & 40 & 40
\end{tabular}

Table 3 shows that the value of significance for self-efficacy is $0.182(p>0.05)$. It means that the hypothesis is accepted. There is no correlation between students' self-efficacy and their language anxiety. This finding agrees with a study by Cubukcu (2008), who suggests that no correlation found between the two variables.

\section{Discussions}

This study illuminates the level of students' self-efficacy and language anxiety in learning Speaking. In the EFL context, it shows that students have a relatively high self-efficacy level. This finding speaks to another previous study, which suggests a similar result (Roshandel, Ghonsooly, \& Ghanizadeh, 2018). However, another study also highlighted that students in EFL context possess a moderate self-efficacy level (Genc, Kulusakli, \& Aydin, 2016).

According to Bandura (2006), self-efficacy influences the learners' attainments and performances. Students who have high self-efficacy realize the importance of learning Speaking and believe that they have enough capacity to gain success. Moreover, they also exert greater effort to perform the tasks given. Efficacious feelings of the students will encourage classroom engagements related to motivation, cognitive, and behaviour (Linnenbrink \& Pintrich, 2003), which influence students' academic attainment. It implies that it is important for them to have high self-efficacy. These findings support ideas given by Zahiri, Sibarani, \& Sumarsih (2017) who say that self- 
efficacy influences learners' speaking skill. The lecturer, therefore, should recognize the development of students' language self-efficacy.

As Bandura (1997) proposed, there are some aspects of self-efficacy sources that should be noted by speaking lecturers: students' mastery, vicarious experiences, social persuasion, and emotional state. Mastery experience indicates that prior experiences are keys to students' self-efficacy development because the students who have successfully carried out an assignment often possess better self-efficacy. To boost students' speaking selfefficacy, the lecturers ought to give assignments which are not too difficult. Secondly, observing their peers' successful performance can maintain positive attitude towards their personal abilities, which would likely develop self-efficacy. Therefore, encouraging them to pay attention to their peers' performance can improve their speaking efficacy. According to Law et al (2015), the teacher can also conduct collaborative learning technique to improve the students' self-efficacy because this technique allows students to watch their classmates doing the assignment well. Social persuasion, which comes from others, is the third aspect of selfefficacy. Providing facilitative feedback is one of the effective measures to persuade the students and may improve their speaking skills. Lastly, emotional feelings such as nervousness, anxiety, fear reactions and excitement can influence self-efficacy. Students who have high stress and anxiety levels are unlikely perform better. Since the students may encounter many negative feelings during speaking class, speaking lecturers should create a positive environment for students to improve their speaking efficacy. Gurler (2015) says that students who have high self-efficacy often perform better when compared to those with lower efficacy.

Realizing the importance of self-efficacy, researchers are constantly trying to find ways to improve students' self-efficacy in academic setting, and they agree that self-efficacy may determine students' attainment. Vogt (2008) suggests that self-efficacy is a major aspect in the attainment of undergraduate engineering students. Loo and Choy (2013) say that self-efficacy was the main aspect affecting academic attainment in mathematics, while Louise and Mistele (2011) mention that it is a useful indicator of academic attainment in science and mathematics. In terms of language learning, Nariman-Jahan and Rahimpour (2010) reveal that learners' selfefficacy correlates positively with their English learning performance. Mills, Pajares, and Herron (2007) suggest that French university students' efficacy was significantly linked to their ability in reading. This idea is in line with the idea given by Boakye (2015) who points out that self-efficacy is the best indicator of students' reading ability.

Another fact shows that high self-efficacy may also increase the students' motivation (Saeid, Tan, \& Chan, 2012). They argue that self-efficacy positively affects students' learning motivation in ESL context. In light of this, the teachers need to advocate measures to improve students' self-efficacy and motivation. Blumenthal (2014) explains that there are three ways that the lecturers can do for this: (1) incorporate students' families into the learning process; (2) help students set goals and recognize their progress, and (3) develop strategies to deal with obstacles to learning as they arise. These ideas are supported by Magogwe and Oliver (2007) also highlighted the importance of learning strategy and self-efficacy which was found to have significantly positive relationship with each other. Similarly, Yilmaz (2010) revealed that students possessing good self-efficacy utilise various types of learning strategies.

Regarding the learning anxiety, this research reveals that the students posses moderate anxiety level. This agrees with Bensalem's (2018) finding, which suggests that students possess a moderate anxiety level. This also partially supports Alrabai (2014) and Tianjian's (2010) studies which indicate that learners have moderate to high anxiety level. However, this seems distinctive from another reliable study which highlights a very high level of anxiety (Suleimenova, 2012). This suggests that students have certain degree of anxiety when they have to speak promptly. They also feel that their ability in speaking is inferior compared to their peers. This is distinctive from other studies which suggest that students feel the highest level of anxiety on fear of negative feedback, fear of failure, fear of making mistakes, and limited vocabulary (Alsowat, 2016; Sadighi \& Dastpak, 2017).

This study also examines the relationship between speaking self-efficacy and language anxiety. The data analysis shows that no relationship between the two variables. This finding agrees with another previous study, which suggests a similar result (Cubukcu, 2008). However, this is somewhat distinctive from other studies which 
examine the relationship between self-efficacy and language anxiety. Tuncer \& Dogan (2016) discovered a positive relationship. This implies that self-efficacy has somewhat an influence to language anxiety. Lastly, the majority of studies suggest that self-efficacy affects negatively to anxiety (Bensalem, 2018; Mede \& Karairmak, 2017; Piniel \& Csizer, 2013; Tsai, 2013). Thus, this study is to enrich the repertoire of this field of research as it shows different findings in a different EFL context. Despite the small number of participants, this might contribute to the better understanding of the relationship between speaking self-efficacy and language anxiety in Indonesian EFL context.

\section{Conclusion}

This paper revealed no relationship between self-efficacy and language anxiety in the English speaking class in EFL context. However, it reveals that the students have high self-efficacy and low anxiety level. Therefore, the lecturers should focus on the students' language efficacy by helping them to have a clear understanding about their learning goals, applying various kinds of enjoyable teaching strategies, and creating a good learning atmosphere. At the same time, these activities can also lower the language anxiety level. The lecturers should motivate the students by showing positive attitudes, providing an enjoyable and interesting learning process, and maintaining interactive and friendly teacher-student relationship. By having these qualities, the attainment of the students, especially in speaking skill will be improved. Some recommendations are given as the following:

1. Speaking lecturers need nurture and maintain healthy academic self-efficacy, for example by giving emphasize on students' skill development, providing feedback on progress, giving praise and rewards where possible, encouraging authentic mastery and successful experiences, developing explicit strategy instruction or assisting students to set proximal rather than distal learning goals.

2. Speaking lecturers should also give attention to the learning atmosphere in class that might encourage the students in giving a speech.

3. Since the anxiety is a vital in language learning, the lecturers should also understand their students' profile. Thus, the lecturers should discover, analyze and perceived students' personalities.

4. For researchers, this study can be a reference to carry out future studies in self-efficacy, especially in English language learning, not limited to speaking domain.

5. Future researchers are also recommended to carry out more research related to learning strategy that may increase the students' self-efficacy and anxiety.

\section{Funding statement:}

This research did not receive any grant from other parties and was funded solely by me.

\section{Conflict of interest:}

I have no conflicts of interest to disclose.

\section{References}

1. Alrabai, F. (2014). A model of foreign language anxiety in the Saudi EFL context. English Language Teaching, 7(7), 82-101. https://doi.org/10.5539/elt.v7n7p82

2. Alsowat, H. H. (2016). Foreign language anxiety in higher education: A Practical Framework for reducing FLA. European Scientific Journal, 12(7), 193-220. https://doi.org/10.19044/esj.2016.v12n7p193 
3. Bandura, A. (2006). Guide for constructing self-efficacy scales. In F. Pajares, \& T. Urdan, Self-Efficacy Beliefs of Adolescents. Greenwich: Information Age Publishing.

4. Bandura, A. (1997). In self-efficacy: The exercise of control. New York: Freeman.

5. Bandura, A. (1995). Self-efficacy in changing societies. New York: Cambridge University Press. https://doi.org/10.1017/CBO9780511527692

6. Bandura, A. (1986). Social foundations of thought and action: A social cognitive theory. New York: Prentice Hall.

7. Bensalem, E. (2018). Foreign language anxiety of EFL students: Examining the effect of self efficacy, selfperceived proficiency and sociographical variables. Arab World English Journal, 9(2), 38-55. https://doi.org/10.24093/awej/vol9no2.3

8. Blumenthal, L. F. (2014). Self-efficacy in low-level English language learners. Dissertations, http://pdxscholar.library.pdx.edu/open_access_etds.

9. Boakye, N. A. (2015). The relationship between self-efficacy and reading proficiency of first-year students: An exploratory study. Reading \& Writing, 6(1), 52-60. https://doi.org/10.4102/rw.v6i1.52

10. Burden, P. (2004). The teacher as facilitator: Reducing anxiety in the EFL University classroom. JALT Hokkaido Journal, 8, 3-18.

11. Cook, V. (2000). Linguistics and seconds language acquisition. Beijing: Foreign Language Teaching and Research Press and Macmillan Publisher Ltd.

12. Cubukcu, F. (2008). A Study of the correlation between self efficacy and foreign language learning anxiety. Journal of Theory and Practice in Education, 4(1), 148-158.

13. Gardner, R. (1985). Social psychology and second language learning: The role of attitudes and motivation. London: Edward Arnold.

14. Genc, G., Kulusakli, E., \& Aydin, S. (2016). Exploring EFL learners' perceived self-efficacy and beliefs on English language learning. Australian Journal of Teacher Education, 41(2), 52-68. https://doi.org/10.14221/ajte.2016v41n2.4

15. Gurler, I. (2015). Correlation between self-confidence and speaking skill of English language teaching and literature preparatory students. Research Article, 1(2), 14-19.

16. Hamouda, A. (2012). An exploration of causes of Saudi students' reluctance to participate in the English language classroom. International Journal of English Language Education, 1(1), 1-34. https://doi.org/10.5296/ijele.v1i1.2652

17. Horwitz, E. K., Horwitz, M. B., \& Cope, J. (1986). Foreign language classroom anxiety. The Modern Language Journal, 70(2), 125-132. https://doi.org/10.1111/j.1540-4781.1986.tb05256.x

18. Law, Q. P. (2015). Enhancement of self-efficacy and interest in learning English of undergraduate students with low English proficiency through a collaborative learning programme. American Journal of Educational Research, 1284-1290.

19. Linnenbrink, E. A., \& Pintrich, P. (2003). The role of self efficacy beliefs in student engagement and learnig in the classroom. Reading \& Writing Quarterly, 19, 119-137. 
20. Loo, C. W., \& Choy, J. F. (2013). Sources of self-efficacy influencing academic performance of engineering students. American Journal of Educational Research, 1(3), 86-92. https://doi.org/10.12691/education-1-3-4

21. Louis, R. A., \& Misele, J. M. (2011). The differences in scores and self-efficacy by student gender in mathematics and science. Retrieved July 10, 2017, from International Journal of Science and Mathematics Education: http://link.springer.com/search?query=Louis $+\% 26+$ Mistele + 2011\&search within= Journal\&facet-publication-title =International + Journal + of + Science + and + Mathe matics https://doi.org/10.1007/s10763-011-9325-9

22. Magogwe, J. M., \& Oliver, R. (2007). The relationship between language learning strategies, proficiency, age, and self-efficacy belief: A study of language learners in Bostwana. System, 35, 338-352. https://doi.org/10.1016/j.system.2007.01.003

23. Mede, E., \& Karairmak, O. (2017). The predictor roles of speaking anxiety and English self-efficacy on foreign language speaking anxiety. Journal of Teacher Education and Education, 6(1), 117-131.

24. Mills, N. A., Pajares, F., \& Herron, C. (2007). Self-efficacy of college intermediate French students: Relation to achievement and motivation. Language Learning, 57(3), 417-442. https://doi.org/10.1111/j.1467$\underline{9922.2007 .00421 . x}$

25. Ozuturk, G., \& Hursen, C. (2013). Determination of English language learning anxiety in EFL classrooms. Procedia-Social and Behavioural Sciences, 84, 1899-1907. https://doi.org/10.1016/j.sbspro.2013.07.055

26. Piniel, K., \& Csizer, K. (2013). L2 motivation, anxiety and self-efficacy: The interrelationship of individual variables in the secondary school context. Studies in Second Language Learning and Teaching, 3(4), 523550. https://doi.org/10.14746/ss Ilt.2013.3.4.5

27. Rahimpour, M., \& Nariman-Jahan, R. (2010). The influence of self-efficacy and proficiency on EFL learners' writing. Journal of Instructional Technology and Distance Learning, 7(11), 23-36.

28. Roshandel, J., Ghonsooly, B., \& Ghanizadeh, A. (2018). L2 motivational self-system and self-efficacy: A quantitative survey-based study. International Journal of Instruction, 11(1), 329-344. https://doi.org/10.12973/iji.2018.11123a

29. Sadighi, F., \& Dastpak, M. (2017). The sources of foreign language speaking anxiety of Iranian English language learners. International Journal of Education \& Literacy Studies, 5(4), 111-115. https://doi.org/10.7575/aiac.ijels.v.5n.4p.111

30. Saeid, R., Tan, B. H., \& Chan, S. H. (2012). Self-efficacy in second/foreign language learning contexts. English Language Teaching, 5(1), 60-73. https://doi.org/10.5539/elt.v5n11p60

31. Schunk, D. H. (1991). Self-efficacy and academic motivation. Educational Psychologist, 26(3), 207-231. https://doi.org/10.1207/s15326985ep2603\&4 2

32. Shabani, M. B. (2012). Levels and sources of language anxiety and fear of negative evaluation among Iranian EFL learners. Theory and Practice in Language Studies, 2(11), 2378-2383. https://doi.org/10.4304/tpls.2.11.2378-2383

33. Suleimenova, Z. (2012). Speaking anxiety in a foreign language classroom in Kazakhstan. Procedia-Social and Behavioral Sciences, 93, 1860-1868. https://doi.org/10.1016/..sbspro.2013.10.131

34. Thayne, S. W. (2013). Facilitating language learner motivation: Teacher motivational practice and teacher motivational training. Unpublished MA Thesis, Brigham Young University, Provo, USA. 
35. Tianjian, W. (2010). Speaking anxiety: More of a function of personality than language achievement. Chinese Journal of Applied Linguistics, 33(5), 95-109.

36. Tilfarlioglu, F. T., \& Cinkara, E. (2009). Self-efficacy in EFL: Differences among proficiency groups and relationshipswith success. Novitas Royal, 3(2), 129-142.

37. Tsai, C. (2013). The impact of foreign language anxiety, test anxiety, and self-efficacy among senior high school students in Taiwan. International Journal of English Language and Linguistics Research, 1(3), 1-17. https://doi.org/10.5296/ijld.v3i4.4247

38. Tuncer, M., \& Dogan, L. Y. (2016). Relationships among foreign language anxiety, academic self-efficacy beliefs and metacognitive awareness: A structural equation modelling. International Journal of Learning and Development, 6(2), 31-41. https://doi.org/10.5296/ijld.v6i2.9519

39. Vogt, C. M. (2008). Faculty as a critical juncture in student retention and performance in Engineering Programs. Journal of Engineering Education, 97(1), 27-36. https://doi.org/10.1002/j.21689830.2008.tb00951.x

40. Yilmaz, C. (2010). The relationship between language learning strategies, gender, proficiency, and selfefficacy beliefs: A study of ELT learners in Turkey. Procedia Social Science and Behavioral, 2, 682-687. https://doi.org/10.1016/j.sbspro.2010.03.084

41. Zahiri, A., Sibarani, B., \& Sumarsih. (2017). To what extent do anxiety and self-efficacy effect the EFL students' English monologue speaking skill? International Journal of Education and Research, 5(9), 151-160.

\section{Conflicts of Interest}

I have no conflict of interest to disclose.

\section{Funding Statement}

This research did not receive any grant from other parties and was funded solely by the author.

\section{Autobiography}

My name is Hadriana, a lecturer of English Department - University of Riau. I was born on the 12th of August, 1963. I got my Sarjana Degree in 1986 major in TEFL and in 2009 I got my Master Degree also major in TEFL. In 2014, I got my Ph.Dfrom The National University of Malaysia major in Resource and InformationTechnology. As a lecturer I have responsibilities to teach and to conduct the research that are related to my academic expertise:Educational Technology in English language Teaching. The subjects that I often teach are: Reading Comprehension, Structure, Writing, Media Instructional Design, Micro Teaching, Educational Management Information Systemsand EducationalTechnology Management. During the last five years, I have written twelve articles that are published in various journals: local, national and international. Moreover, I also involve in attending seminar, and so far I have six proceedings of international seminars. 


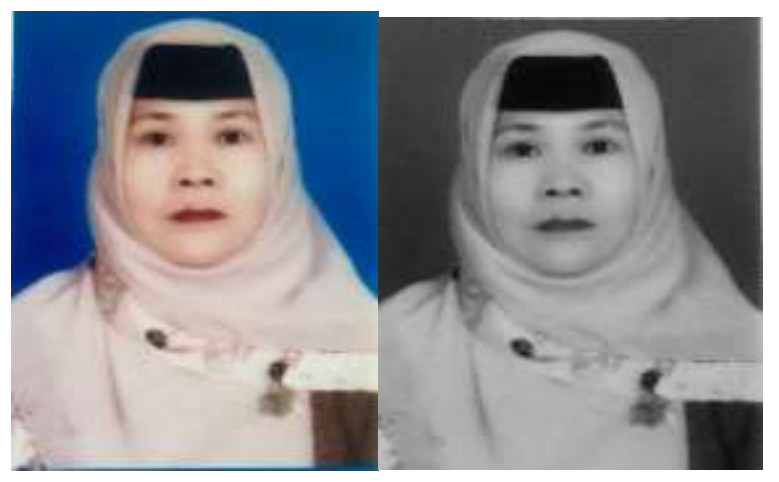

